\title{
Dwakroć eugenika
}

\author{
Maciej BIElawsKi, Higieniści. Z dziejów eugeniki, przeł. Wojciech \\ Chudoba, Wydawnictwo Czarne, Wołowiec 2011, s. 430.
Agata Strzadala, Od Galtona do Watsona. Przemiany pojmowania eugeniki w XIX i w XX wieku, Wydawnictwo Uniwersytetu Opolskiego, Opole 2010, s. 203.

Na fali mody na historię eugeniki przełożono ze szwedzkiego książkę Macieja Zaremby Bielawskiego Higieniści. ${ }^{1}$ Ponad 400-stronicowa książka Bielawskiego jest reportażem historycznym, w aspekcie faktograficznym opartym głównie na źródłach szwedzkich, a co do całości eugeniki - na opracowaniu Daniela J. Kevlesa, In the Name of Eugenics: Genetics and the Uses of Human Heredity. ${ }^{2}$

Autor, polski Żyd urodzony w roku 1951 i osiadły w Szwecji w 1969, miał za młodu ścisłe związki z socjalizmem. W latach siedemdziesiątych dwudziestego wieku był członkiem trockistowskiej Förbundet Kommunist (Ligi Komunistycznej), po jej rozpadzie miał — jak podaje Wikipedia — „odwrócić się od lewicy”. Jak wspominał, ${ }^{3}$ na studiach został ,,szalejącym marksistą”, a przeszło

\footnotetext{
${ }^{1}$ Oryginał: Maciej BIELAWSKI, De rena och de andra: om tvångssteriliseringar, rashygien och arvsynd, Bokförlaget Dagens Nyheter, Stockholm 1999, s. 346.

${ }^{2}$ Por. Daniel J. Kevles, In the Name of Eugenics: Genetics and the Uses of Human Heredity, University of California Press, Berkeley 1985.

${ }^{3}$ Por. wywiad Katarzyny Bielas, „Jak pan się przechrzci, będzie panu łatwiej”, Gazeta Wyborcza 19 maja 2011.
} 
mu, gdy po krótkim studiowaniu dwóch fakultetów i spłodzeniu dziecka poszedł do pracy jako operator dźwigu, w związku z czym doświadczył prawdziwego życia. Do tego jest synem z drugiego małżeństwa dra Oskara Stanisława Bielawskiego, aktywisty eugenicznego i zasłużonego reformatora psychiatrii, które ten zawarł już po wojnie z żydowską lekarką Elżbietą Imierowską (Immerdauer).

Książka jest dobrze napisana, znać wieloletnią praktykę dziennikarską autora. Geograficzny zasięg rozważań jest szeroki, obejmuje oprócz Europy i USA także Amerykę Łacińską i Japonię. W tej ostatniej akcja sterylizacyjna nabrała impetu wbrew początkowemu oporowi wobec ustaw eugenicznych i tradycjonalizmu Japończyków, trwając przynajmniej do połowy ostatniej dekady ubiegłego wieku. Bielawski niejednokrotnie podkreśla, że ofiarami eugeniki negatywnej padały głównie kobiety. Skutki łączenia postępowego feminizmu z destrukcyjną ingerencją w najintymniejszą dziedzinę natury kobiecej może niektórym dać powody do złośliwej satysfakcji, ale przecież mało w tym śmiesznego, tyle że problem ideologicznie bardzo ciekawy. Poparcie kobiet dla eugeniki wyrażało się nie tylko za pośrednictwem ruchu feministycznego: wywiady dla Archiwum Eugenicznego (Eugenics Records Office), przez prawie 30 lat głównego ośrodka badawczego eugeniki anglosaskiej, przeprowadzały głównie studentki biologii.

Eugenicy, próbując przejąć ster ewolucji człowieka, nieuchronnie zamierzali przekroczyć granicę człowieczeństwa, niewiele zważając, że dziedzinę tradycyjnej moralności opuścili już dawno. Miejmy nadzieję, że dziś, gdy fala eugeniki powraca, stanie się to w końcu bardziej widoczne. Bielawski słusznie zauważa, że chętnemu przekroczeniu granic dotychczasowej moralności towarzyszyła, tak w Niemczech, jak i w Skandynawii (dodajmy, że i w Ameryce), redefinicja chrześcijaństwa polegająca między innymi na ponownym uwydatnieniu karykatury motywu predestynacji. Główną okoliczność sprzyjającą akceptacji ustawodawstwa eugenicznego upatruje wszak Bielawski nie w samej religii, ale w bizantyjskim charakterze kultury protestanckiej, a szczególnie kultury luterańskiej Szwecji. Istnienie państwowej służby zdrowia i opłacanie pastorów z pensji rządowych oznaczało, że dwa zawody zaufania publicznego i wymagające powołania uległy etatyzacji. Stosunek lekarza do pacjenta był relacją urzędnika do pe- 
tenta, a nie usługodawcy do klienta. Natomiast duszpasterstwo zawierało element ciągłego nadzoru: pastorzy tworzyli nieoficjalny korpus policyjny inwigilujący parafian. Ów wieśniaczy naród wykazuje po dziś dzień nie tylko oszczędność, ale wręcz jawne skąpstwo, o czym wie dobrze, kto spędził ze skądinąd miłymi Szwedami trochę czasu. „Jaka mać taka nać. [...] Stwierdzona przez Galtona przerażająca rozrodczość «niepełnowartościowych» nie jest niczym nowym dla chłopa, który zawsze uskarżał się, że najlepiej rosną chwasty” (s. 137).

$Z$ drugiej strony Szwedzi tradycyjnie pokładają duże zaufanie w swoim państwie, którego władze zdały sobie w pewnej chwili sprawę, że oszczędzanie na zasiłkach staje się palącą koniecznością. Tu Bielawski dostrzega już nie okoliczność sprzyjającą, lecz bezpośrednią przyczynę uruchomienia programu sterylizacji w roku 1935 i jego kontynuowania aż do roku 1976. Niedługo przed uchwaleniem prawa eugenicznego małżeństwo inżynierów społecznych, Alva i Gunnar Myrdalowie (ona noblistka pokojowa, on noblista z ekonomii) wydali Kryzys problemu ludnościowego (Kris i befolkningsfrígan, Bonniers, Stockholm 1934), receptę przeciw wyludnianiu się Szwecji. Jednym z elementów przepisu było ubezpłodnianie jednostek rozmnażających się w sposób nieodpowiedzialny. Myrdalowie byli socjologami, a jest to nauka jawnie szatańska, bowiem poczęta przez Comte'a w grzechu pychy. Dzieli się na dwie równie znieprawione na mocy pochodzenia gałęzie: doktrynerską (lepiej by napisać „ględzącą") i szpiegującą. Pierwsza małpuje rzetelną filozofię, podstawiając za mądrość fałszywe recepty na to, jak nie narobiwszy się zrobić wszystkim dobrze. Druga nieustannie wszystkich inwigiluje w poszukiwaniu odchyleń od stanu idealnego.

Praca Bielawskiego nie jest na szczęście o wszystkim. We wstępie czytamy: „Nie minęło [...] trzydzieści lat od zniesienia autorytarnych ustaw o przymusowej sterylizacji [...], a nauka obiecuje oczyścić nasze geny z cech niepożądanych, tym razem nie przez państwo - tylko przez rodziców, oraz, prawdopodobnie, przez towarzystwa ubezpieczeniowe. [...] Do czego może doprowadzić eugenika sprywatyzowana, tego jeszcze nie wiemy" (s. 9). Właściwie już wiemy, skoro - by użyć frazy z Bergmanna - na naszych oczach wykluwa się embrion zamknięty w jaju węża. Bezpośrednie skutki demograficzne na przykład dla Chin czy Indii, gdzie zabijanie nienarodzonych i głodzenie narodzonych dziewczynek już zakłóciło naturalną proporcję płci, nie przemówiły do ro- 
zumu ludziom żyjącym w tradycjach dwóch wielkich, starożytnych cywilizacji. Tym bardziej trudno liczyć na otrzeźwienie Zachodu.

Miejscami książce nie zaszkodziłoby bezpośrednie odniesienie do tekstów oryginalnych. Tytuł rozdziału 7. „Zatwardziałe serca, rozmiękczone mózgi” jest parafrazą znanego fragmentu Gilberta Keitha Chestertona: „they have discovered how to combine the hardening of the heart with a sympathetic softening of the head" („eugenicy odkryli, jak połączyć utwardzenie serca z rozmiękczeniem mózgu"; Eugenics and Other Evils, 1922, s. 54). W tekście zdarzają się też zgrzyty stylistyczne: na przykład na s. 360 występuje kolokwializm „moralny fart”, choć przyznać trzeba, iż poziom językowy thumaczenia jest niezły.

Zgoła inny charakter ma praca Agaty Strządały Od Galtona do Watsona, stanowiąca książkową wersję jej doktoratu. Jest to przegląd historii idei eugenicznych od starożytności do czasów współczesnych. Autorka uznaje ideologię eugeniczną za nieweryfikowalną naukowo (s. 184), z czym trudno się do końca zgodzić. Jej aspekt statystyczny jest wszak weryfikowalny. Oczywiście, że ideologie jako takie z definicji weryfikowalne nie są, jednak okazują się mniej lub bardziej adekwatne w danym środowisku społecznym. Eugenika tej adekwatności nie utraciła, co najwyżej potrzebowała genetycznego alibi, o czym Strządała pisze przy okazji Hermanna J. Müllera, który dokonał odpowiedniej rewizji podstawowych założeń, między innymi odciął eugenikę od jawnych odniesień do kwestii rasowych (rozdz. 3.).

Eugenika miała być racjonalnym samosterowaniem ewolucją człowieka, stąd nieuniknione okazały się odniesienia do doktryn rozwoju świata organicznego. Autorka przywołuje dwóch głównych ewolucjonistów angielskich dziewiętnastego wieku: Darwina i Spencera, a jak zwykle w tle mamy doktrynę Lamarcka. Nigdy dość przypominania, iż to Spencer poprzedzał Darwina jako ideolog walki o byt i przeżycia najlepiej dostosowanych, a nie odwrotnie. Twierdzenie, jakoby ten ostatni nie uznawał dziedziczenia cech nabytych (s. 145), jest grubym uproszczeniem. Nie będziemy rzecz jasna rozstrzygać, który z nich obu okazał się lepszym lamarckistą. 
Efektywność poprawy wartości biologicznej osobników ludzkich drogą mieszaństwa rasowego staje pod znakiem zapytania wobec niezgody co do intensywności i trwałości zjawiska heterozji (bujności mieszańców) u ludzi. W sposób wyważony, jednak ze wskazaniem na korzyści społeczne wynikające z heterozygotyczności populacji, rzecz przedstawił Napoleon Wolański. ${ }^{4}$ Natomiast Strządała powołuje się na badania krzyżówek hotentocko-burskich z niemieckiej Afryki południowo-zachodniej (s. 53 i 121-122). Chodzi o tzw. „bastardów z Rehoboth", o czym pisał Eugen Fisher. ${ }^{5}$ Obserwacje Fishera okazały się niekonkluzywne, zresztą wobec wątpliwości co do wyodrębniania ras oraz w ogóle niewielkiej liczby zbadanych pod tym kątem przypadków krzyżowania międzyrasowego efekty heterozji ocenia się zasadniczo innymi metodami, analizując skutki łączenia pojedynczych par pochodzących z odległych genetycznie populacji. Co do ogólnej hipotezy o psychobiologicznej patologiczności potomków par różnorasowych — skutkiem ich dysharmoniczności, to jest ujawniania się niedobranych cech fenotypowych — chodzi nie tylko o skłonność do gruźlicy, także na przykład do nowotworów. Pisał o tym na przykład Jan Czekanowski. ${ }^{6}$

Spory dotyczące koncepcji rasy zostały jednostronnie zreferowane w rozdziale 6.: wychodziłoby na to, że populacjoniści „wygrali” spór z typologami. I tu mamy do czynienia z walką ideologiczną — autorka zapomniała, iż populacjonizm wprzęgnięto w rydwan lewicowo-liberalnej utopii społecznej, o czym dowodnie świadczą dokumenty cytowane w pkt. 6.5., choćby propagandowy esej Lesliego Clarence'a Dunna „Rasa a biologia”. ${ }^{7} \mathrm{Z}$ merytorycznego punktu

${ }^{4}$ Por. Napoleon Wolański, „Zjawisko heterozji u człowieka”, w: Adam KoŁątau (red.), Zjawisko heterozji u zwierząt, Ossolineum, Wrocław 1972, s. 179-321; Napoleon WolaŃski, „Heterozja człowieka", w: Adam KoŁątaj et al., Biologiczne podstawy heterozji, PWN, Warszawa 1973, s. 307-353.

${ }^{5}$ Por. Eugen FisCHER, Die Rehobother Bastards und das Bastardierungsproblem beim Menschen. Anthropologische und ethnographische Studien am Rehobother Bastardvolk in Deutsch-Südwest-Afrika, Gustav Fischer, Jena 1913.

${ }^{6}$ Por. Jan Czenanowski, Podstawy teoretyczne antropologii i ich konsekwencje, wyd. 2, TN KUL, Lublin 1947, s. 21-23; Jan CzeKanowski, Antropologia polska w międzywojennym dwudziestoleciu 1919-1939, Towarzystwo Naukowe Warszawskie, Warszawa 1948, s. 99-100.

${ }^{7}$ Por. Leslie Clarence Dunn et al. (red.), Rasa a nauka. Trzy studia, przeł. Janina Dembska, PWN, Warszawa 1961. 
widzenia typologia i populacjonizm są komplementarne, a nie przeciwstawne.

Język pracy jest zanieczyszczony poprawnością polityczną: czemu „Afroamerykanie” (np. s. 111, 182), a nie po ludzku „Murzyni”? Dlaczego nazwisko Sergiusza Bułgakowa zostało zanglicyzowane na „Bulgakov”, tak w tekście, jak i w bibliografii? Skandalicznie wygląda terminologia dotycząca islamu (s. 169): nie „bektaszyści”, lecz „bektaszyci”, a co do „alewitów”, to nie wiadomo, czy jednak nie „alawici”, religia synkretyczna na pograniczu islamu. Nie „Charia”, ale „szariat”! — który nie jest żadnym „prawem kanonicznym”. Autorka twierdzi, jakoby muzułmanie nie mieli duchowieństwa — owszem, szyici mają całkiem dokładny odpowiednik.

W zakończeniu książki znajdujemy celne rozróżnienie między przemianami samej doktryny eugenicznej a środkami jej realizacji. Te drugie ulegają względnie szybkiej wymianie. Natomiast doktryny wykazują trwałość znacznie przekraczającą pojedyncze pokolenie, sięgającą, jak można sądzić, nawet stuleci co zgadza się z rzędem trwania faz światopoglądów w kontekście formacji kulturowych. Eugenika oparta została na ideach utylitarno-progresywistycznych, dopasowanych do fazy kulturalistycznej, w której od kilku stuleci tkwi formacja zachodnia. Tymczasem mało co zapowiada jakiś impuls, któryby miał doprowadzić do przełomu ideologicznego.

Robert Piotrowski 